\title{
BAHASA DAN KONSEP KEBAHASAAN DALAM MUQODIMAH KARYA IBNU KHALDŪN (1332 M - 1406 M)
}

\section{Erfan Gazali}

Erfan Gazali@gmail.com

Jurusan Bahasa Arab dan Sastra Arab

IAIN Syekh Nurjati

- Received: 02.08.2019

- Accepted: 30.10 .2019

- Published online: 05.11.2019

\begin{abstract}
This research aims to describe Ibn Khaldinn's ideas on the concepts of language that he wrote in his great work 'al-muqaddima'. A review of this ideas using Gadamer's philosophical hermeneutic approach. This paper is descriptive, analytical, interpretative and comparative-synthesis. Interpretation is used to provide an explanation of the thought of Ibn Khaldin based on the understanding of researcher in interpreting the texts of al-muqodimah. The comparative-synthesis aspect is carried out to compare Ibn Khaldun's linguistic ideas with modern linguistic concepts, with the aim of finding a common point of ideas between Ibn Khaldun and modern linguistic theories. Some concepts of Ibn Khaldün language that apparently have similarities with modern language ideas are: lughah, ifädah al-kalām, fi'l lisāni, malakah, al-qoshd, fitrah, etc.
\end{abstract}

Kata Kunci: Malakah, Performance, Language Acquisition, Ibn Khaldun, Muqaddima.

\section{Pendahuluan}

Eksistensi Ibn Khaldūn dalam pusaran multidipliner ilmu secara realitas telah diakui dan dikagumi oleh kaum cendikiawan, baik dari kalangan barat maupun timur, bagi para cendikiawan barat sosok Ibn Khaldūn dipandang sebagai bapak historiografi dan sosiolog sejati (Gates, 1967; Glasse, 2008), peletak pondasi ilmu-ilmu sosial (Haddad, 1977:195) bahkan jauh sebelum munculnya sejumlah tokoh pemikir besar Eropa dibidang sosiologi, sejarah, dan filsafat (Issawi, 2003:19; Boulakia, 1971), ia pun dianggap sebagai pendiri sosiologi timur (Dhaouadi, 1990:319), di tangannya, sejarah menjadi sesuatu yang rasional, faktual, dan bebas dari unsur mitos dan takhyul.

Kapabilitas Ibn Khaldūn tidak hanya dikenal sebagai sejarawan dan sosiolog ulung saja, ia pun diakui sebagai salah satu filosof terbesar dari 
dunia Islam (Hitti, 1968:568; Deen.S.M, 2007:157) ia juga seorang politikus (Enan, 1941) hampir seperempat dari umurnya bergelut dalam dunia politik membantu pemerintahan Maroko dan Andalausia (Wafi, 1984), ia juga seorang ekonom (Oweiss, 1988; Boulakia, 1971) peletak pemikiran dasar-dasar ekonomi fundamental yang menjadi cikal bakal utama lahirnya ekonomi modern (Boulakia, 1971).

Taburan puja-puji kejeniusan yang disanjungkan oleh para cendikiawan atas sosok Ibn Khaldūn, terutama ketika hadirnya mahakarya monumental yang telah ia tulis yaitu kitab Muqaddimah atau Ibn Khaldun's Prolegomena, karya yang sejatinya bermakna 'pendahuluan' ini merupakan bagian pertama dari sebuah kitab terbaiknya yang lain, bernama kitab 'ibar. Arnold Joseph Toynbee (1988) memuji kitab muqadimah sebagai 'the greatest work of its kind that has ever yet been created by any mind in any time or place'. (sebuah maha karya penulisan yang belum pernah dikarang oleh manusia manapun dan kapanpun). Sebuah karya pertama yang memuat secara lengkap disiplin ilmu kontemporer (Cooke, 1983).

Pendekatan ilmiah yang dimilliki Ibn Khaldun sangat khas dan asli dari produk kematangan intelektual, sehingga memiliki kontribusi secara ilmiah yang menghantarkan karyanya sebagai maha karya bidang filsafat sejarah dan sosiologi. Fokus perhatian utama dari karya monumental ini adalah mengidentifikasi fakta psikologis, ekonomi, lingkungan dan sosial yang berkontribusi terhadap kemajuan peradaban manusia dan juga sejarahnya (Asante,2014). Dari sekian banyak torehan konsep yang ia sumbangkan dalam ilmu pengetahuan sebagaimana dipaparkan di atas, apa dan bagaimana Ibnu Khaldun memandang bahasa dan kebahasaan dalam karya monumentalnya al-Muqodimah?

\section{Metode}

Jenis penelitian yang digunakan adalah penelitian kualitatif (qualitative research), dengan pendekatan hermeneutika-fenomenologi (hermeneutica-phenomenology) yang dikembangkan Hans Georg Gadamer dikenal yang dengan istilah teori affective historis.

'we should learn to understand ourselves better and recognize that in all understanding, whether we are expressly aware of it or not, the efficacy of history is at work' (Gadamer, 2006) 
pesan dari teori ini adalah pemahaman seorang penafsir akan dipengaruhi oleh situasi hermeneutik tertentu yang melingkupinya, baik itu berupa tradisi, kultur maupun pengalaman hidup. Karena itu, pada saat menafsirkan sebuah teks seorang penafsir harus atau seyogyanya sadar bahwa dia berada pada posisi tertentu yang bias sangat mewarnai pemahamannya terhadap sebuah teks yang sedang ditafsirkan.

Pemilihan hermeneutik bertujuan untuk menelaah makna dari simbol-simbol teks dalam upaya menemukan ide pemikiran Ibnu Khaldun terhadap bahasa dan kebahasaan. Menurut Gadamer (dalam Prihananto, 2014) fokus hermeneutika adalah untuk membangkitkan makna tentang tema utama pembicaraan, dan bukan semata-mata hanya terbatas menjelaskan maksud asli dari penulis teks. Makna bagi Hermeneutika Gadamerian adalah sesuatu yang dicari, dikonstruksi, dan direkonstruksi oleh penafsir sesuai konteks penafsir dibuat sehingga makna teks tidak pernah baku, ia senantiasa berubah tergantung dengan bagaimana, kapan, dan siapa pembacanya.(Rahardjo, 2007).

Tulisan ini bersifat deskriptif, analitis, interpretatif dan komparatifsintesis. Deskriptif-analitis digunakan untuk mendeskripsikan struktur teks karya Ibnu khaldun terkait bahasa dan mendeskripsikan makna sintaksis teks dengan pembacaan heuristik dan pembacaan hermeneutik yang disertai deskripsi ide-ide pemikiran Ibnu Khaldun yang terkandung pada al-muqodimah terkait bahasa yang dilihat dari konteks-konteks pembelajaran bahasa dan psikologi bahasa. Adapun analitik, dalam arti bahwa data-data yang didapatkan, baik dalam bidang pemikiran tokoh maupun dalam konsep-konsep bahasa dan kebahasaan dianalisis berdasarkan kecukupan data yang dimiliki penulis.

Interpretasi digunakan untuk memberikan penjelasan terhadap pemikiran Ibnu Khaldun sesuai dengan tarap pemahaman penulis terhadap teks-teks al-muqodimah. Aspek komparasi-sintesis dilakukan untuk membandingkan antara ide-ide kebahasaan Ibnu Khaldun dengan pandangan-pandangan tokoh-tokoh linguistik modern yang ditujukan untuk menemukan titik kesamaan pikiran Ibnu Khaldun dalam teori-teori teori kebahasaan modern.

Data yang digunakan dalam kajian ini terdapat dua jenis. Yaitu: data primer berupa kitab al-Muqodimah karya Ibnu Khaldun terbitan Dar Al-Balkhi - Damaskus tahun 2004. Dan data sekunder berupa buku-buku 
dan juga hasil kajian terkait pemikiran Ibnu Khaldun. Adapun metode menganalisis data mengunakan analysis interactive model Miles \& Huberman (2007) dengan tahapan analisis data meliputi : pengumpulan data (data collection), reduksi data (data reduction), penyajian data (data display), dan penarikan kesimpulan atau verifikasi (conclutions).

\section{Hasil dan Pembahasan}

\subsection{Sekilas Riwayat Hidup Ibnu Khaldun}

Ibn Khaldūn adalah cendikiawan Muslim yang berasal dari Tunisia dengan nama asli 'Abdur-Raḥmān bin Muhammad bin Khaldūn Al-Ḥaḍrami al-Maghribi al Maliki, lahir di Tunisia pada awal Ramadhan $732 \mathrm{H}$ yang bertepatan dengan 27 Mei $1332 \mathrm{M}$ dan wafat di Mesir pada 19 maret 1406 M/808 H (Enan, 1941 ; As-Sakhawi, 1992)

Panggilannya adalah Abu Zayd, gelar yang disandangnya adalah Waliyudin, gelar Abu Zayd (ayahnya Zayd) disinyalir sebagai nama anaknya yang tertua, adapun penyematan gelar Waliyuddin, disematkan lantaran menjabat sebagai pemangku bidang hukum di Mesir, sedangkan nama Ibnu Khaldun sendiri dinisbatkan kepada kakeknya yang kesembilan, Khalid bin Ustman; ia adalah orang pertama dari keluarganya yang memasuki kota Andalusia bersama para pejuang dari arab pada masa pembebasan negeri Andalusia. Sudah menjadi perilaku yang lumrah di masyarakat Andalus dan Maroko pada masa itu bila setiap nama mengalami penambahan huruf waw dan nun pada nama belakang mereka sebagai bentuk penghormatan kepada pemilik nama tersebut (Wafi, 1984) dan juga bagian dari penamaan sebuah klan keluarga.

\subsection{Karya-karya Ibnu Khaldun}

Karya-karya Ibn Khaldūn bersifat multidisiplin keilmuan dengan tingkat 'kematangan' metode yang diakui oleh para ilmuan di zaman setelahnya, sayangnya hanya beberapa saja yang masih bisa temukan hingga sekarang. Diantara :

a. Lubābu l-Muhassal fi Ușūl al-Dìn

Ini adalah karya pertama Ibn Khaldun berupa ringkasan dengan beberapa komentar atas karya teolog dan juga seorang filosof muslim Fakhrudin al-Razi (w.1206 M) dengan judul 
Muhassal afqar al-mutaqaddimin wa al-muta'-akhkhirin min al-'ulama' wal-hukama' wa 'l-muta-kallimin. Kitab ini ditulis saat berusia 19 tahun ketika di Tunisia dibawah arahan gurunya Syaikh Muhammad ibnu Ibrahim al-Ābilī (ahli bidang ilmu logika, MetaPhysical Sciences dan Matematika, Astronomi, ilmu Alam dan Musik) (Molins, 2006; Gu, 2014:126), dalam kitab ini ibn khaldun berbicara tentang dasar-dasar sistem berlogika (Akrami, 2015) dan pada tahun 1952 kitab ini dipublikasi dalam bahasa Inggris oleh Lucio Rubio dengan judul A Treatise in Logic (Fischel, 1967).

b. Sifã'u s-Sā'il Litahzibi-l Masāil fi Radd alā-t Tașawwuf

Sebuah karya yang menjelaskan tentang sufistik, buku ini ditulis ibn Khaldun sekitar tahun 1373 M di Fes,Maroko (Gu, 2014)

c. al-Muqaddimah

Kitab ini adalah magnum opus Ibn Khaldun yang monumental dan populer dengan sebutan Muqaddimah Ibn Khaldūn atau Muqaddima yang dalam bahasa yunani berarti Prolegomena. Beberapa pemikir modern menganggapnya sebagai karya pertama yang mengkaji tentang disiplin ilmu secara universal, mencakup filsafat sejarah, Sosiologi, Demografi, Historiografi, peradaban manusia, ilmu pengetahuan (science), sejarah budaya, dan ekonomi (Alatas, 2006; Oweiss, 1988; Gates, 1967; Boulakia, 1971).

al-Muqaddimah sendiri sebenarnya merupakan pengantar untuk kitabnya yaitu kitabu-l 'ibar wa diiwanu-l mubtada wa-l khabar, fi ayyami-l arab wa-l 'ajam wa-l barbar wa man asharahum min dzawi sulthon al akbar (Book of Lessons, Record of Beginnings and Events in the history of the Arabs and Foreigners and Berbers and their Powerful Contemporaries). Penulisan Mukaddimah terjadi dipertengahan tahun $779 \mathrm{H}$, dengan hanya memakan waktu lima bulan saja (Ibn khaldun, 1952), yang kemudian kemudian ia matangkan dan sempurnakan kembali selama empat tahun ketika berdiam di benteng Bani Salamah, kitab ini meliputi enam bab besar mengenai peradaban manusia yang dimuat dalam 650 halaman' (Wafi, 1984). 
d. Kitab al-Ibar wa Diwān al-Mubtada' wa al-Khabar fi Ayyāmi al-'Arab wa al-'Ajam wa al-Barbar wa Man 'Ansharuhum min Dzawis Sulthani al-Akbar.

Kitab ini disebut secara singkat dengan kitab al-'Ibar (sejarah Umum), terdiri dari 7 jilid berisi kajian sejarah, yang didahului oleh kitab Muqaddimah pada jilid pertama (Syahid et al., 2008)

e. Al-Ta 'rïf bi Ibn-Khaldūn wa Rißlatuhu Gharbān wa Sharqān

Buku ini disebut juga Al-Ta'rif , cendikiawan barat menyebutnya sebagai autobiografi. Buku ini adalah bagian terakhir dari kitab al-'ibar, yang berisikan catatan kehidupan Ibn Khaldun. Ia menulisnya secara sistematis dengan mengunakan metode ilmiah walau tampak menyebar dalam beberapa bab tapi semua saling berhubungan satu dengan yang lain.

Ibn Khatib (2009) menyebutkan bahwa Ibn Khaldūn juga memiliki karya-karya di bidang Aritmatika, Puisi (berupa penjelasan dan komentar Qasidah Burdah karya al-Busiri), logika (Resume dan komentar karya-karya Ibn Rusd, kitab al-Muqadamāt al-Mumhidāt dan Bidāyatu-l Mujtahid Wa Nihāyatu-l Muqtasid), dan Usul Fiqh (berupa Sarh Ar-rajz fi Usul figh).

Terdapat pula kitab Tazkir al-Sahawan, yaitu sebuah risalah hadist yang penjelasan satu hadist Nabi yang diriwayatkan oleh Asma bint 'amis RA selain itu terdapat pula kumpulan surat-surat Ibn Khaldun untuk para hakim yang terkumpul dalam kitab muzilu-l manām 'ani-l hikāmi-l anām. (Abu Saneeb, 2012)

\subsection{Konsep Bahasa dan Istilah kebahasaan dalam sudut pandang Ibn Khaldun}

\section{a. Lughah (langage) dan Lisān (langue)}

Definisi bahasa ditulis Ibn Khaldun dalam pasal 46 bab ilmu nahwi dalam kitabnya Muqaddima (2/367), dinyatakan bahasa adalah :

$$
\text { ناشئ عن القصد بإفادة الكارم، فلا بُدَّ أن تصير ملكة وتلك العبارة فعل لسائي }
$$




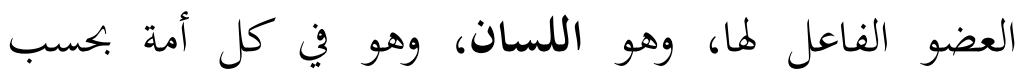

اصطالحاتم. (Ibn Khaldun, 2004)

... sebuah ekpresi penutur tentang maksud -keinginan-nya, ekspresi tersebut adalah tindak tutur yang muncul dari sebuah kesadaran atau kesengajaan berupa peryataan yang terstruktur dalam tuturan, oleh karena itu, (bahasa) harus harus menjadi keterampilan yang dibiasakan dan bersifat stabil (terus menerus) pada anggota tubuh yang memproduksi bahasa yaitu lisan (lidah). Adapun -Sistem, struktur dan penerapan aktifitas- lisan di setiap bangsa didasarkan dengan istilah (kosakata dan kaedah kebahasaan) mereka masing-masing.

Dalam struktur teks di atas terdapat beberapa istilah yang bila dikaji memiliki kesamaan konsep dengan istilah dan teori ilmu pengetahuan modern diantaranya :

1) القصد / al-qasd/, kesadaran atau keinginan yang disengaja, dalam istilah konsep transendental Edmund Huserl disebut sebagai intensionalitas (lihat Kuswarno, 2009). intensionalitas atau kesengajaan adalah orientasi fikiran terhadap suatu objek. Sesuatu tersebut bisa nyata bisa juga tidak nyata. Intensionalitas sendiri berarti kesadaran yang selalu mengarah pada sesuatu (consciousness on something), seperti kesadaran akan waktu, kesadaran akan tempat, dan kesadaran akan eksistensi diri sendiri. Pandangan ini pula digunakan oleh Ibn Hisyam (1991) dalam mendefinisikan konsep tuturan :

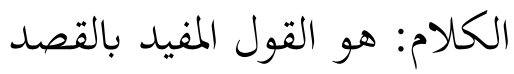

Secara umum kalimat tersebut mengandung arti bahawa 'tuturan adalah ucapan yang terstruktur terkandung makna yang disertai kesadaran / kesengajaan dalam bertutur'

2) ملكة /malakah/. Kata malakah dimaknai oleh Abdussalam (1995) dan Samarah (2011) sebagai kebiasaan (habit) dan 
kompetensi. Konsep ini akan dibahas secara khusus dalam tulisan ini.

3) /al-lisān/, istilah al-lisan dalam pandangan Ibnu khaldun adalah istilah khusus bukan makna leksikal yaitu lidah tetapi konsep ilmu, sebagaimana sebutkan Yunus (1966) dalam karyanya Al-Usus-l Fanniyah lil naqdi-l Adabi bahwa kata lisan yang digunakan Ibnu Khaldun menunjukkan makna khusus sebagai sebuah sistem kebahasaan yang dimiliki oleh masing-masing masyarakat bahasa.

Bila istilah lisan yang dimaksud adalah sistem kebahasan yang bersifat kolektif dan menjadi sistem nilai dalam berkomunikasi maka ini sepadan dengan term langue yang diusung oleh Ferdinand de Saussure atau dalam kotegori semiotik disebut system menurut AJ Greimas atau Code Roman menurut Yacobson (Phillips \& Tan, 2005). Konsep Langue sendiri dimaknai sebagai The language system [langue] is not a function of the speaking subject, it is the product which the individual registers passively (de Saussure, 1966).

Bila sistem bahasa dikaitkan dalam sistem pengunaan organ bicara berupa lidah, maka objek kajiannya adalah terkait titik bunyi dan sifat bunyi sebuah bahasa. Dalam kajian linguistik modern fonetik artikulatoris atau dengan istilah lain fonetik organis, fonetik fisiologi, Fonetik artikulatoris menurut Gleason (1961) dan Verhaar, (2010) adalah ilmu yang mengkaji dan mendeskripsikan mekanisme organ bicara (alat-alat ucap) manusia dalam menghasikan bunyi bahasa.

4) فعل لساني / fíl lisāni, istilah ini merujuk pada aktifitas tindak tutur. Menurut Maksan (1994) tindak tutur adalah suatu ujaran yang secara langsung dan tidak langsung meminta orang lain untuk bertindak atau melakukan sesuatu seperti memerintahkan, mengajak, menawarkan, tidak mengizinkan dan sebagainya. Secara umum konsep ini memiliki kesamaan dengan teori teori tindak tutur atau tindak ujar (speech act) yang diusung oleh John Langshaw Austin (1911-1960). Austin, 
(1975) menyebutkan bahwa pada dasarnya pada saat seseorang mengatakan sesuatu, dia juga melakukan sesuatu. Ia membedakan tiga jenis tindakan yang dapat diwujudkan oleh penutur yaitu (a) tindak lokusi (locutionary acts), yaitu tindak mengucapkan sesuatu dengan makna kalimat sesuai dengan makna kata itu (di dalam kamus) dan makna kata itu menurut makna sintaksisnya; (b) tindak ilokusi (illocutionary acts), yaitu tindakan lantaran ujaran mengandung daya atau kekuatan (force) yang mengharuskan si penutur untuk melaksanakan isi tuturannya; dan (3) tindak perlokusi (perlocutionary acts) mengacu pada efek yang ditimbulkan oleh ujaran yang dihasilkan.

Dalam definisi tersebut diatas pula, Ibnu Khaldun mengunakan istilah lughah dan lisan untuk dua konsep yang berbeda. Kata Lughah dimaknai sebagai tindakan yang mengungkapkan perasaan yang ada dalam benak penutur sedangkan lisan adalah sistem tuturan. Kata lughah secara leksikal berarti 'Bahasa' dalam bahasa Indonesia, adapun secara konseptual, Ibn Khaldun memandang bahasa sebagai:

1) Sarana yang membedakan manusia dari mahluk lainnya dan menjadi media utama dalam komunikasi dan mengekspresikan pandangan dan perasaan. Ibnu Khaldun menekan fungsi bahasa sebagai sarana komunikasi. Hal ini sejalan dengan fokus aliran fungsional, sebagaimana yang diutarakan oleh Alawi (2004) tentang dua hal mendasar terkait fungsi utama bahasa yaitu berkomunikasi dan mengidentifikasi tujuan komunikatif struktur bahasa alamiah;

2) Fenomena pikiran manusia yang muncul secata kolektif dan bukan individu, ia merupakan hasil kesepakatan komunitas masyarakat terkait simbol-simbol tuturan yang digunakan dalam berkomunikasi. Ini menjadi alasan beranekaragamnya bahasa manusia karena setiap komunitas bahasa memiliki istilah yang beragam untuk menandai atau menamakan dan memaknai sesuatu. 
Menurut Ibn Khaldun (dalam Fadlullah, 2009) keberadaan sebuah bahasa tidak bisa dilepaskan dari dimensi sosial masyarakat karena kompetensi kebahasaan seseorang dalam merangkai struktur bahasa didasari oleh struktur kebahasaan sebuah masyarakat bahasa. kondisi ini akan membimbing dalam menyusun maksud dan tujuannya antar individu dan anggota masyarakat bahasa tersebut.

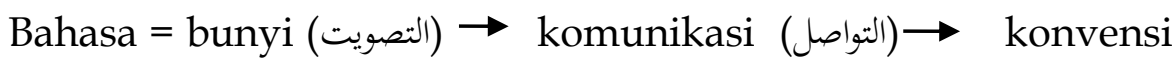
(masyarakat bahasa) (الجماعي العقد);

3) Perilaku fi'lu lisani (tindak tutur).

Secara karakteristik berdasarkan definisi di atas, ditarik kesimpulan bahwa bahasa menurut Ibnu Khaldun mengandung ciri yang melekat sebagaimana berikut:

1) Bahasa sebagai sistem pengetahuan dalam berkomunikasi dan berekspresi;

2) kuantitas leksikon dapat berbeda antar masyarakat bahasa;

3) Bahasa terdiri dari bunyi yang berhubungan dengan makna;

4) Bahasa adalah aktifitas lisan yang didasari kesadaran;

5) Bahasa adalah konvensi masyarakat bahasa;

6) Berbicara adalah hasil akhir dari kompetensi dan menjadi proses utama dalam berbahasa

b. Malakah lisaniyah (Kompetensi kebahasaan) dan al-Adä' alLughowi (Performasi kebahasaan)

Ibnu Khaldun mengilustrasikan bahasa sebagai kerajinan yang membutuhkan pembiasaan secara teknis . Pada pasal $47 \mathrm{di}$ dalam al-Muqaddimah, ibn Khaldun (2004) menyatakan bahwa:

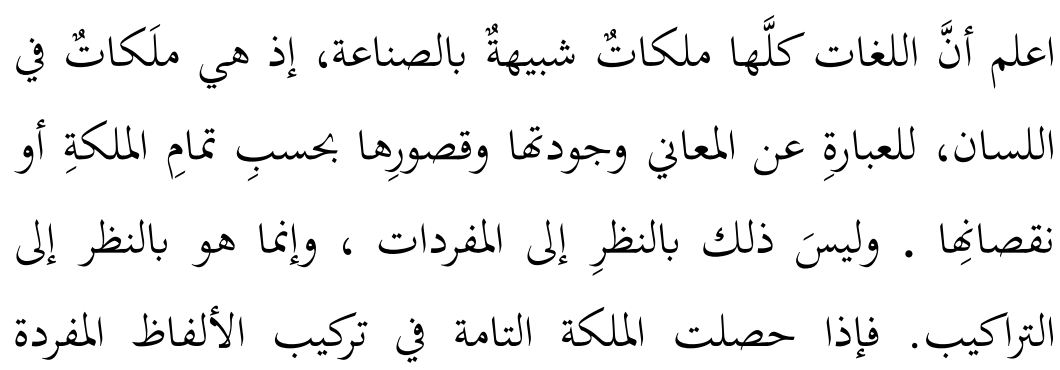




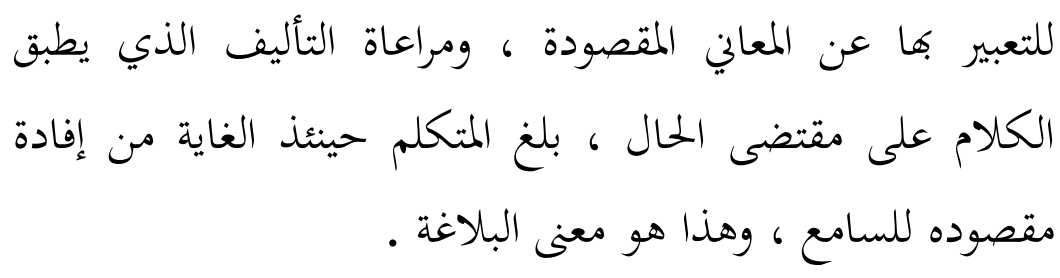

Sejatinya semua bahasa adalah malakah (keterampilan) yang serupa dengan kerajinan -yang membutuhkan pembiasaan secara teknis-. adapun malakah bahasa terletak pada lisan (lidah, organ bertutur) yang bertujuan untuk mengekspresikan ide-ide. Baik atau tidaknya kualitas ekpresi tersebut tergantung pada kesempurnaan dari malakah itu. Parameternya bukan dinilai dari kata-perkata (kosakata) tetapi struktur kalimat. Seorang penutur yang memiliki malakah yang baik (dalam berbahasa), mampu menggabungkan kata perkata dalam mengekspresikan ide-idenya, mampu mengamati bentuk komposisi kalimat sesuai konteks, mampu menyampaikan pesan kepada pendengar berdasarkan keinginan yang ingin diutarakan. Maka inilah yang dinamakan kefasihan.

Secara leksikal kata malakah dalam kamus arab al Wasith adalah:

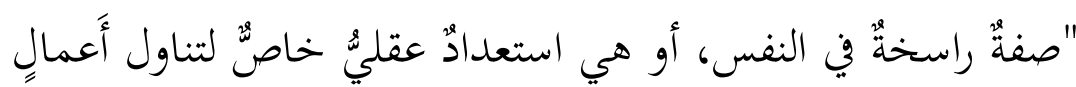

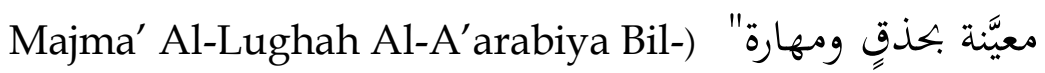

(Qohiro, 2004

Yaitu karakter dasar yang melekat secara mapan dalam masingmasing individu yang menjadi dasar pencapaian kemampuan kerja tertentu secara terampil. Adapun menurut Abdussalam (1995) dan Samarah (2011) kata malakah dimaknai sebagai kebiasaan (habit) dan kompetensi.

Secara konseptual Ibnu Khaldun membagi malakah dalam dua kategori: (1) Malakah Fitriyah, dan (2) malakah Sinaiyah. Kedua konsep ini dibedakan berdasarkan bagaimana terwujudnya dan proses capaiannya. Kategori pertama telah ada dalam diri setiap orang secara fitrah (bakat, potensi dasar dan bawaan sejak lahir) dalam konsep Chomsky disebut bekal kodrati atau innate idea dan 
Innate Knaowledge (lihat Cowie, 2017). Adapun kategori kedua hadir keberadaanya melalu proses latihan terus menerus yang kemudian disebut sebagai Sina'ah (keterampilan).

Proses mencapai malakah Sinaiyah diutarakan ibnu khaldun muqodimah jilid 3 halaman 256 :

$$
\begin{aligned}
& \text { والملكات لا تحصلُ إلا بتكرار الأفعال لأن الفعل يقعُ أولاً وتعودُ منه للذاتِ }
\end{aligned}
$$

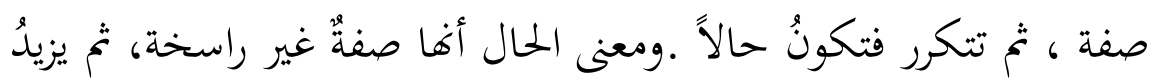

$$
\begin{aligned}
& \text { التكرارُ فتكونُ ملكةً أي صفةً راسخة }
\end{aligned}
$$

Malakah tidak dicapai kecuali melalui tindakan berulang-ulang karena tindakan berada pada tahapan pertama yang memberikan kontribusi dalam pembentukan sebuah karakter. perilaku mengulang adalah sebuah kondisi yang harus dijalani. Kondisi ini disebut karakter yang tidak mapan. Tetapi pengulangan yang berkelanjutan yang menjelma menjadi sebuah kompetensi itulah yang disebut malakah atau karakter yang mapan.

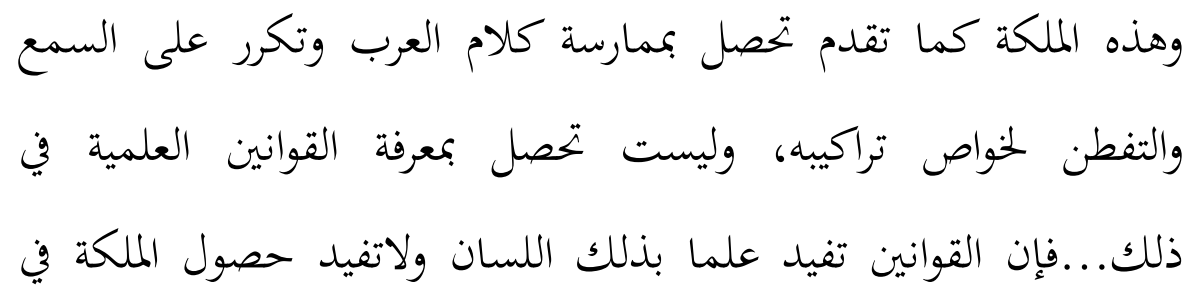

Malakah diperoleh dengan cara berlatih berbicara bahasa (atau bahasa asing lainnya), mendengar secara berulang, dan pembiasan menyusun struktur kalimat dengn tepat, dan bukan dicapai dengan hanya sekedar memahami kaedah-kaedah ilmiah bahasa, karena kaedah kebahasaan hanya berguna memberi pengetahuan bahasa (penjabaran secara ilmiah) dan tidak pada aspek kecakapan berbahasa.

Ibnu Khaldun berpendapat bahwa malakah adalah sebuah karakter dan warna bahasa yang tidak bercampur dalam satu waktu. Teknik terbaik mencapainya adalah dengan cara 'alamiah'. Baginya kompetensi bahasa tidak datang secara instan, namun secara bertahap dalam sebuah proses pemerolehan bahasa. Malakah tidak dapat dikuasai hanya dengan mengetahui gramatika 
sebagai aturan tata bahasa saja ia hanya bisa dicapai dengan cara latihan, pembiasaan dan mengulang terus menerus (Ibn khaldun, 2011).

1) malakah merupakan kecakapan atau kompetensi seseorang terkait pemahamannya atas struktur sebuah bahasa dan bukan sebatas tataran kosakata. struktur bahasalah yang membangun makna yang diinginkan pembicara kepada pendengar;

2) Malakah dicapai melalui perilaku yang berulang (repitisi);

3) Tahapan dalam mencapai malakah (1) tindakan pembentuk karakter (2) halah atau kondisi (3) malakah : keterampilan berupa kebiasaan yang muncul;

4) kompetensi ini akan dimanfaatkan dalam perilaku berbahasa (performansi), yaitu tindak tutur atau pemahaman akan tuturan.

Ibn Kaldun (2004) juga memperingatkan terhadap faktorfaktor yang dapat merusak malakah seseorang :

Pertama, Melemahnya kompetensi berbahasa. Menurut Ibn Khaldun kemampuan berbahasa akan melemah jika seorang berinteraksi dengan bahasa lain secara konstan. Ia mencontohkan tentang bagaimana kompetensi bahasa Arab melemah secara bertahap setelah berkomunikasi dengan orang-orang non-Arab, maka kompetensi mereka mulai menjadi lemah pasca interaksi yang konstan dengan bahasa asing.

Kedua, pencampuran bahasa. Menurut Ibnu Khaldun kompetensi bahasa ibu dapat berkurang bila interaksi antara bahasa ibu dan beberapa bahasa lain memunculkan kompetensi bahasa baru, apa lagi percampuran ini yang terjadi antara dua atau lebih jenis bahasa. misalnya ketika Arab Muslim menaklukkan bagian besar wilayah di dunia, maka terjadi interaksi ini antara bahasa Arab dengan bahasa-bahasa lokal negeri taklukan

Ketiga, perubahan kompetensi, Ibnu Khaldun menjelaskan bahwa perubahan ini dapat diamati dari struktur kalimat yang 'berbelok'. Ini terjadi ketika penutur arab klasik (fusha) menyebar masuk ke kawasan Suriah, Yordania, Lebanon, \& Palestina, Mesir, 
dan Afrika Utara, Aljazair, dan Maroko maka kompetensi penutur bahasa ini berubah terpengaruh wilayah sekitar.

Istilah Malakah Lisaniyah sepadan dengan kategori linguistic competence yang digunakan Noam Chomsky dan langue yang digunakan oleh de Saussure (Abdussalam 1995; Samarah 2011).

\section{1) linguistic competence dan linguistic performace}

Noam Chomsky dan ahli bahasa lainnya, memberikan dua istilah kebahasaan yaitu Kompetensi kebahasaan dan performansi kebahasaan. kompetensi kebahasaan bukanlah istilah evaluatif. Sebaliknya, ini mengacu pada pengetahuan bahasa bawaan yang memungkinkan seseorang untuk mencocokkan suara dan makna. Dalam bukunya Aspect of Theory of Syntax Chomsky, (1965) Chomsky menulis :

"We thus make a fundamental distinction between competence (the speaker-hearer's knowledge of his language) and performance (the actual use of language in concrete situations)."

Chomsky memisahkan istilah kompetensi dan performansi; Kompetensi adalah pengetahuan tentang sesuatu yang bersifat abstrak, yang berisi pengetahuan tentang kaidah, parameter atau prinsip-prinsip, serta konfigurasi-konfigurasi sistem bahasa. Kompetensi kebahasaan merupakan pengetahuan gramatikal yang berada dalam struktur mental di belakang bahasa. Kompetensi bahasa dikenal juga kompetensi tata bahasa (grammatical competencel) atau bahasa bawaan (Innate language). Konsep ini berbeda dengan performansi bahasa. Performansi adalah pemakaian bahasa itu sendiri di dalam keadaan yang sebenarnya. Dengan kata lain, performansi merupakan tuturan yang aktual. Performansi linguistik mengacu kepada proses-proses kognitif, kesadaran, dan perilaku yang dipergunakan oleh seseorang di dalam penggunaan pengetahuan linguistiknya secara aktual.

Singkatnya, kompetensi melibatkan "mengetahui" (knowing) bahasa dan performansi melibatkan "perilaku" (doing) sesuatu dengan bahasa tersebut. sangat sulit untuk menilai kompetensi tanpa menilai performansi. Dalam 
kenyataan yang aktual, performansi itu tidak sepenuhnya mencerminkan kompetensi kebahasaan. Dikemukakan oleh Chomsky bahwa dalam pemakaian bahasa secara konkret banyak ditemukan penyimpangan kaidah, kekeliruan, namun semua itu masih dapat dipahami oleh pembicara-pendengar karena mereka mempunyai kompetensi kebahasaan.

\section{Kesimpulan}

Berdasarkan kajian teks terhadap ide-ide kebahasaan Ibnu Khaldun melalui karyanya Al-Muqodimah dapat diambil kesimpulan bahwa, tergambar bahwa sekalipun Ibnu Khaldun terkenal sebagai sosiolog dan sejarawan tetapi ide-ide briliannya tentang bahasa mampu melampaui melewati horison dinamika konsep pengetahuan dimasanya hingga menembus masa modern saat ini. beberapa konsep bahasa yang terbukti memiliki kesamaan ide diantaranya: pandangan bahwa adalah sistem komunikasi, pemikiran ini ini secara umum memiliki kesamaan ide tetang fungsional bahasa sebagimana yang diusung Halliday. Selain itu konsep al-lughah dan al-lisan yangmemiliki kesamaan ide dengan konsep langage dan langue (Saussure), konsep malakah lughawiyah dan adä' Lughawi yang memiliki kesamaan dengan konsep competence vs performance (Chomsky) dan langue dan Parole (Saussure), istilah fi'l lisāni dengan teori speech act (Austin), konsep al-qosd dengan intensionality (Huserl).

\section{Referensi}

Abdussalam, A. S. (1995). The Psycholinguistic Theories in the Muqaddimah of Ibn Khaldun. Intellectual Discours, 3(2), I81-196.

Abu Saneeb, H. M. (2012). Ibn Khaldūn Faqih. In Mu'tamar ibn Khaldun Allamah al-Syarq wa al-Gharb. Nablus: Najah University.

Akrami, M. (2015). Ibn sina's Two - Partite vs. Nine - Partite Logicography. In A. Koslow \& A. Buchsbaum (Ed.), The Road to Universal Logic (hal. 1-12). Basel: Birkhäuser/ Spinger.

Alatas, S. H. (2006). The Autonomous, the Universal and the Future of Sociology. Current Sociology, 54(1), 7-23.

Alawi, H. I. (2004). Qodoya al-Lughah al-Arabiyah fi al-Lisaniyat alWazifiyah. Majalla ALam al-FIkr, 33(2), 200-210.

As-Sakhawi, S. (1992). Ad-Dhou-u al-Lami' li Ahli al-Qorn at-Tasi'. (M. J. AlQosimy, Ed.). Beirut: Dar al-Jayl. 
Asante, M. K. (2014). The History of Africa: The Quest for Eternal Harmony (2 ed.). New York: Routledge.

Austin, J. L. (1975). How To Do Things With Words. (F. O. Urmson \& M. Sbisa, Ed.). Oxford: Oxford University Press.

Boulakia, J. D. (1971). Ibn Khaldûn: A Fourteenth-Century Economist. Journal of Political Economy, 79(5), 1105-1118.

Chomsky, N. (1965). Aspects of a Theory of Syntax. Cambridge,MA: MIT Press.

Cooke, M. (1983). Ibn Khaldun and Language: From Linguistic Habit to Philological Craft. Journal of Asian and African Studies, 18(3-4), 179-188. https://doi.org/10.1177/002190968301800304

Cowie, F. (2017). Innateness and Language. In E. N. Zalta (Ed.), Stanford Encyclopedia of Philosophy (Fall 2017). The Metaphysics Research Lab Center for the Study of Language and Information Stanford University.

de Saussure, F. (1966). Course in General Linguistics. (C. Bally, A. Sechehaye, A. Riedlinger, \& W. Baskin, Ed.). New York: McGraw-Hill Book Company.

Deen.S.M. (2007). Science Under Islam: rise, decline and revival.

Dhaouadi, M. (1990). Ibn Khaldun: The Founding Father of Eastern Sociology. International Sociology journal, 5(3), 319-335.

Enan, M. A. (1941). Ibn Khaldūn: His Life and Works. Lahore: Syekh Muhammad Ashraf Kashmiri Bazar.

Fadlullah. (2009). Al-lughah wa-l adab 'inda Ibn Khaldun. Majallah AlQism Al-Arabi, 16, 121-153.

Fischel, W. J. (1967). Ibn Khaldūn in Egypt: His Public Functions and His Historical Research (1382-1406) a study in Islamic historiography. Berkeley and Los angeles: University of California Press.

Gadamer, H. (2006). Hans-Georg Gadamer. (J. Weinsheim \& D. G. Marshall, Penerj.). London and New York: Continum.

Gates, W. E. (1967). The Spread of Ibn Khaldûn's Ideas on Climate and Culture. Journal of the History of Ideas, 28(3), 415-422.

Glasse, C. (2008). The New Encyclopedia of Islam (3 ed.). Maryland: Rowman \& Littlefield Publishers.

Gleason, H. A. (1961). An Introduction to Descriptive Linguistics. New York: 
Holt, Rinehart and Winston.

Gu, S. (2014). A Cultural History of the Arabic Language. North Carolina: Mc farland \& company, inc, Publisher.

Haddad, L. J. (1977). A Fourteenth-Century Theory of Economic Growth And Development. Kyklos : international review for social sciences., 30(2), 195-213.

Hitti, P. K. (1968). History Of The Arabs. New York: St. Martin's Press.

Ibn Hisyam. (1991). Mughni-l labib 'an kutub-l a'arib. (M. mahyudin abdu-l Hamid, Ed.). Beirut: al-makbah al-'asriyah.

Ibn khaldun, A. bin M. (1952). Al-Ta'rif bi Ibn Khaldun Wa Rihlatuhu Syarqon Wa Gharban. (M. ibn T. Al-Tonji, Ed.). Cairo: Lajnah al-Ta'lif wa altarjamah.

Ibn khaldun, A. bin M. (2011). Mukaddimah Ibnu Khaldun. (M. N. Ridwan, Ed., A. Irham, Masturi Supar, Malik Zuhri, Penerj.) (3 ed.). Jakarta: Pustaka Al-Kautsar.

Ibn Khaldun, A. ibn M. (2004). Muqaddimah Ibn Khaldun. (A. M. AdDarwees, Ed.) (Vol. 2). Damascus: Dar Al-Balkhi.

Ibn Khatib, Lisan Ad-deen. (2009). Al-Ihatoh fi Akhbar Ghornatoh. (B. AlDaroji, Ed.) (1 ed., Vol. 4). AL-Jazair: Dar Al-Amal Lid-dirosat.

Issawi, C. P. (2003). An Arab Philosophy of history: Selections from the prolegomena of Ibn Khaldun of Tunis (1332-1406). Cairo: AUC Press.

Kuswarno, E. (2009). Fenomenologi: metode penelitian komunikasi: konsepsi, pedoman, dan contoh penelitiannya. Bandung: Widya Padjadjaran.

Majma' Al-Lughah Al-A'arabiya Bil-Qohiro. (2004). Mu'jam al-Wasith (4 ed.). Cairo: Makbah as-Syuruq ad-Dauliyah.

Maksan, M. (1994). Ilmu Bahasa (2 ed.). Padang: IKIP Padang Press.

Miles, M. B., \& Huberman, A. M. (2007). Analisis Data Kualitatif: Buku Sumber Tentang Metode-Metode Baru. (T. R. Rohidi, Penerj.). Jakarta: Universitas Indonesia.

Molins, J. V. (2006). Ibn Khaldun: The Mediterranean in the 14th Century : Rise and Fall of Empires. (N. G. Millán, Ed.). sevilla: Fundación José Manuel Lara.

Oweiss, I. M. (1988). Ibn Khaldun Father of Economics. In I. M. Oweiss \& G. N. Atiyeh (Ed.), Arab Civilization:Challenges and Responses from Arab Civilization (hal. 112-127). New York: State University of New York 
Press.

Phillips, J., \& Tan, C. (2005). Langue and Parole. Diambil 2 Agustus 2019, dari https:/ / www.litencyc.com/php/stopics.php?rec=true\&UID=662

Prihananto. (2014). Hermeneutika Gadamer Sebagai Teknik Analisi Pesan Dakwah. Jurnal Komunikasi Islam, 04(1), 143-167.

Rahardjo, M. (2007). Hermeneutika Gadamerian: Kuasa Bahasa dalam Wacana Politik Gus Dur. Malang: UIN Malang Press.

Samarah, A. Y. (2011). Ibn Khaldun and Some Classic Views in 20th Century Linguistics. Theory and Practice in Language Studies, 1(11), 1521-1530. https://doi.org/10.4304/tpls.1.11.1521-1530

Syahid, A., Thaha, I., Azra, A., Ambary, H. M., Ridwan, K., Madjid, N., ... Daradjat, Z. (2008). Ensiklopedi Islam (Jilid 2). (A. A. Dahlan, B. Yatim, Q. Shihab, Y. Yusuf, M. Ardani, \& M. A. Suma, Ed.). Jakarta: PT. Ichtiar Baru van Hoeve.

Toynbee, A. J. (1962). A Study of History, Vol 3: The Growths of Civilizations.

(D. C. Somervell, Ed.) (2 ed.). london: Oxford University Press.

Verhaar, J. W. M. (2010). Asas-asas Linguistik Umum. Yogyakarta: Gadjah Mada University Press.

Wafi, A. A. al-W. (1984). Abqariyat Ibni Khaldun. Riyadh: Syirkah Maktabat Ukaz.

Yunus, A. H. (1966). Al-Usus-l Fanniyah lil naqdi-l Adabi (2 ed.). Kairo: Daru1 ma'rifa. 